\title{
THE PERCEPTION AND PARTICIPATION OF COMMUNITY IN DEVELOPING SMART ECO-VILLAGE DESTINATION IN THE TOURIST VILLAGE PAKSABALI AS A TOURISM ICON IN KLUNGKUNG DISTRICT-BALI
}

\author{
I Wayan Pantiyasa, Putu Devi Rosalina \\ Sekolah Tinggi Pariwisata Bali Internasional \\ pantiyasa@stpbi.ac.id
}

\begin{abstract}
The development of tourist village is a government policy that is expected to improve the economy of the community, expanding the employment vacancies, and alleviating poverty. Expanding the employment vacancies lead to improving the welfare of rural communities. The purpose of this study was to determine the perception and participation of local people in Paksebali in the development of smart eco-village destination in the tourist village of Paksebali, Dawan subdistrict, Klungkung regency. The approach was done by distributing to 30 respondents (Purposive sampling).

The collected data were primary and secondary data using the techniques of observation, interview and documentation. The collected data were then analyzed by qualitative descriptive analysis. The results of this study showed that the perception of the development of smart eco-village Paksebali tourist village has been widely known. The community very agreed and supported the implementing the sapta pesona (seven ways of enchantment). People hoped the development of tourist village could promote the village and improve the welfare of their life. Community participation in the development of tourist village was done starting from planning, developing facilities and infrastructure, managing, and monitoring and evaluation.
\end{abstract}

Key words: Tourism Potential, Public Perception, Community Participation, Tourist Village, Smart eco-village destination 


\section{INTRODUCTION}

\subsection{Background}

In the Strategic Plan of Klungkung Regency's Tourism Office in 2013 2018, Klungkung Regency explained that the vision of Klungkung Regency development is "Realization of Community Based Tourism Based on Tri Hita Karana in Improving the Welfare of Society". Tri Hita Karana Community Based contains the understanding of tourism development which always prioritizes community participation in aligning development, which related to God, amongst society, and environment (Tri Hita Karana), the development of tourism that preserve the cultural life of Balinese Hindu society and the tourism which gets world recognition in increasing tourists' visit. Meanwhile, Improving Public Welfare implies that there is an active role of society in the development will eventually become in harmony of interest, therefore it could create security and comfort, which will lead to the welfare of society that can be achieved. Referring to the vision of the Tourism Office of Klungkung Regency, the things that need to be done is to develop a safe, comfortable, and attractive tourism destination by promoting the diversity of tourism potential based on Balinese culture which inspired by Hinduism, developing integrated, effective, efficient and qualified tourism marketing; building facilities and infrastructure in harmony, as well as developing good service to the community.

Klungkung regency is one of the districts in Bali that has a variety of uniqueness, both beautiful nature as well as the richness of the culture. In 2016, the Government of Klungkung Regency began working on the concept of City Tour with the aim of boosting the tourists' visit to the city of Semarapura. The Government conducted the physical development to create branding of Semarapura City as City Tour. If there is a city tour, there would be certain that rural tourism is interesting to develop. According to Infonawacita.com (2017), the government through the Ministry of Cooperatives and SMEs (Small and Medium Enterprises) fully supports the development of villages in Klungkung-Bali as a potential tourist village. There are about 14 villages that have been designated as tourist villages, such as Tihingan Village, Timuhun, and Bakas in Banjarangkan District; Kamasan Village, Tegak, Budaga, and Gelgel in Klungkung Sub-district; Desa Besan and Pesinggahan in Kecamatan Dawan; and Jungutbatu Village, Lembongan, Ped, Batukandik and Tanglad Village in Nusa Penida Subdistrict. Therefore, the determination of the tourist village will synergize with the discourse of the Bali Government, which targets the development of 100 tourist villages until 2018.

Besides, according to infonawacita.com (2017), the Klungkung Regent I Nyoman Suwirta revealed that Klungkung district government has issued a decision letter in stipulating Paksebali Village Dawan Subdistrict, Klungkung as one of the tourist village of Klungkung regency. In addition, Klungkung district government also helped to improve the local village infrastructure. Klungkung District Government seeks to have shuttle bus to the village. This is for tourism development, such as city tour to the villages in Klungkung.

According to Bali Travel News (2017), although Paksebali is not a priority in Klungkung Regency, it could become the only village which is ready to carry the name of a tourist village. Besides it has been designed in some of its attractions such as Kali Unda, Paksebali Village also began to develop agro-tourism by making 
tracking pathways in the hills surrounding the Village area. In the online magazine Bali Travel News (2017), head of Paksebali Village revealed that Paksebali Village has the potential of tourist attraction in the form of tedung crafts, pedape, upakara tools with distinctive ornaments of Paksebali. In addition, Paksebali Village has a natural tourist attractions, such as Tukad Unda and hilly areas with a beautiful and natural view. The potential of tourism strongly supports the development of tourism in Klungkung regency.

However there are still some obstacles in the development of tourism in Paksebali Village, for instance: 1) There are still many potential attractions that have not been well managed, then lack of tourism promotion, which gives impact to the less interest; 2) Lack of making breakthroughs and coordination with related institutions and as well as minimum promotion through electronic media; 3 ) The number of foreign and domestic tourist visit to Paksebali Village is less compared to the number of tourist visit to several tourist destinations in Klungkung Regency. This is also emphasized by Pradnyana (2015), that in the development of Paksebali tourist village, Klungkung Regency is constrained by low funds, the lack of participation from the government and the community to promote tourism creatively and in the delivery of information. The marketing tools are still in the printed form, such as brochures, pamphlets, posters, and books.

In order to develop tourism by implementing mutually beneficial relationships between villages and cities, the concept of eco village can be a solution in the development of tourism in the future. According to GEN (2000) in Shodiq (2009), Eco village is a spatial and territorial concept that pays attention to the quality of the population and the ecological quality holistically as it involves all dimensions of living creatures. Eco village is a regional development, community and the quality of the sustainable natural environment. Thus, it is expected that villagers will have improved welfare without damaging the environment.

To develop tourism marketing requires the development in the form of a digital marketing. The development of Android-based travel applications will help to introduce the tourism sector efficiently and effectively. It could also facilitate the tourists to access all the available information about tourist destinations. So that tourist visits to destinations would be increasing. According to Yustina, travelnews.com (2015), stated that promotion through online media is believed to be more effective in improving the movement of tourists to reach the target of 20 million tourists visit in 2019. It is also emphasized by Minister Arief Yahya at the event of Pewarta Wisata Indonesia Award at Gedung Sapta Pesona, Jakarta which stated that technology and lifestyle have changed, so the effectiveness of online media is four times better than conventional media.

Prabowo, R.C. mentioned that online media is a means of communication in which everything is very rapid, for instance interacting, arguing, exchanging information, knowing the news through internet network as well as fresh information. It is also delivered in more efficient and to the reader / audience. Online media is very different from conventional media, it has the rapidity to make an interaction, more efficient, cheaper, faster to get a new information and updated. So that online media become one of important component in establishing tourism in Indonesia.

To actualize the development of Paksabali Tourist Village in online media based, it needs to develop tourist village which leads to the smart village. Smart 
village is a wider meaning of smart city. Its development concept applies villagebased information and communications technology as a complex interaction between the various systems within (Nashuilia, 2015). Thus, it could give benefit to its citizens effectively and to improve the quality of life, reducing the cost and consumption source. The development of tourist village Paksebali Klungkung regency, will not be able to run without the support and participation of citizens. The maximum support or community participation in tourist village development will be realized if there is a good and comprehensive perception of tourist village development.

\subsection{Research Problems:}

According to the background, the research problems could be formulated as follows:

a) How is the perception of the local community of Paksebali towards the development of smart eco-tourism destination?

b) How is the community participation in the development of Smart EcoVillage Destination tourism village in Paksabali Village, Klungkung Regency, Bali Province?

\subsection{The Research Purposes}

The specific purposes of this research are:

a) Analyzing the villagers' perceptions of paksebali towards the development of smart eco-tourism destination

b) To understand the community participation in Smart Eco-Village Destination development in Paksabali Village, Klungkung Regency, Bali Province 


\section{LITERATURE REVIEW}

\subsection{Tourist Village}

Tourist village is a form of integration between attractions, accommodation, and supporting facilities presented in a community life structure that blends with the prevailing rules and traditions. A tourist village has a unique appeal (it can be a unique physical environment of the rural environment, as well as the socio-cultural life of the community) that is wrapped naturally and attractively so that the rural attraction can draw tourist visits to the village (Ministry of Culture and Tourism, (2011: 1). Priasukmana \& Mulyadi (2001) argued that a tourist village is a rural area that offers a whole atmosphere that reflects the authenticity of the countryside both from socio-economic life, social culture, customs, everyday life, possessing typical building architecture and village spatial structure, or unique and interesting economic activities and has the potential to develop various components of tourism, such as attractions, accommodation, food, beverages, souvenirs and other tourists' needs

The definition is also reinforced by the Law of the Republic of Indonesia No. 10 of 2009 on Tourism, which defines that the potential of tourism is anything that has the uniqueness, beauty and value in the form of diversity of natural wealth, culture and man-made products that become the target or purpose of tourist visits. According to Cooper et al (1993) states that there are 4 (four) components that must be possessed by a tourist attraction, such as Attraction, Accessibility, Amenities and Ancillary services. Yoeti (2002) that the success of a tourist area is very dependent on the 3A of Attractions, Accessibilities and Amenities. Madiun (2008) mentions that an additional component that is at the core of the development of tourism itself is Community Involvement.

\subsection{Community Based Tourism Management}

Tourism management is a planning, organizing, mobilizing and controlling action undertaken to determine and achieve predetermined targets through the utilization of human resources and other resources in tourism. Tourism management should refer to management principles that emphasize the values of environmental sustainability, community and social values that enable the tourists to enjoy their tourism activities and benefit the welfare of local communities. According to Murphy (1988), Larry D, Peter F, Wayne D (2010) in Sunaryo (2013) states that the development of tourism should be a community-based activity. The prior factor that the resources and uniqueness of the local community are either physical elements or non-physical (traditions and cultures) should inherent in the community, then it must maintain a major movement in tourism.

Sunaryo (2013) also added that to create tourism development run well, then well managed, the most fundamental thing to do is how to facilitate the wide involvement of local communities in the development process and maximizing the value of social and economic benefits of tourism activities for local communities. Local communities have an equally important position as one of the stakeholders in tourism development, in addition to government and private industry. Adimihardja (1999) in Sunaryo (2013) defines the empowerment of society as a process which does not only develop the economic potential of the powerless society, but also 
must strive to increase the dignity, confidence, and self-esteem as well as maintaining the local cultural values.

In the development of community-based tourism according to Suansri (2003) in Rahayu et al (2015: 18) mentions the principles of Community-Based Tourism should be done through: 1) recognizing, supporting, and promoting community ownership in tourism; 2) engaging community members from every stage of tourism development in its various aspects, 3) promoting pride in the community; 4) improving the quality of life; 5) ensuring environmental sustainability; 6) protecting the uniqueness and cultural characteristics of local communities; 7) developing cross-cultural learning; 8) giving respect for cultural differences and human dignity; 9) distributing advantages and benefits proportionately to members of the community; 10) contributing to a certain percentage of revenues earned for community development; and 11) highlighting the authenticity of public relations with the environment.

\subsection{Public Perception}

According to Rakhmat (2011) perception is the experience of the objects, events, or relationships obtained by concluding information and interpreting the message. Heriyanto (2014) stated that the perception is a process of sensing, stimulus received by individuals through sensory devices which are then interpreted so that individuals can give views, understand and can interpret about the stimulus received. Robbins (2001) suggests that there are 3 (three) factors that can affect public perception, such as: perception stakeholders, target or object, situation. Tunjugsari et al (2017) also explained that perception is a process that starts from sight to form the challenge that occurs within the individual so that the individual is aware of everything in the environment through the senses he owns.

\subsection{Public Participation}

Adisasmita (2006) explains that community participation is a community empowerment with the role and activity of planning and implementation of development of the program or project. It is the actualization of availability and willingness or the ability of society to sacrifice and contribute to the implementation of development. Four forms of community participation such as participation of thought, physical, expertness and skills, and property (Director General of PMD Directorate General for Village Community Development in Sudria munawar, 2006). The forms of participation lead to the development of the tourist village that is the participation as the involvement of the community in the contribution of ideas related to the deficiency or the advantages of the tourist village, physical energy with the involvement of the community in building the facility or infrastructure of the tourist village, the expertness and skills by involving the community in the efforts that can support additional attractions of tourist villages, property with passive community involvement if not actively participating.

\subsection{Eco Village}


Capra in Jafar (2009) suggested that eco village principles can be applied both to villages or cities for the development and management as well as providing solutions for human or community needs, while at the same time providing environmental protection and improving the quality of life for all options. It is based on a deep understanding that living things and everything is interconnected, then ecovillage is a form of human interaction to the environment to achieve sustainability. According to Nurlaelih in Astrini (2013), ecovillage is an environment-based village concept that can overcome urban environmental problems at this time. According to Subintomo in Astrini (2013), ecovillage can be translated as a green village that seeks to create an environmentally friendly settlement area. Green Village implements the preservation of environmental functions in realizing sustainable development, both preserving functions on environmental components (biotic, abiotic and socio-economic and cultural components and public health). In the development of tourist village with ecovillage based concept, tourism can be built with various facilities such these activities: Eco-lodge, Eco-recreation, Eco-education, Eco-research, Eco-energy, Eco-development, Eco-promotion.

\subsection{Smart Village}

Smart Village is a development of the notion of smart city which has been previously popular. According to Nijkamp (2009) in Mujiyono (2016) argued that smart city is defined as a city which is capable of utilizing human resources, social capital and modern telecommunications infrastructure to create sustainable economic growth and proper high quality of life with resource management through government in the community based tourism. Cohen (2012) in Mujiyono (2016) suggested that smart city is a broad approach, integrated in improving the efficiency of the operation of a city, improving the quality of life of its population, and increasing the growth of its regional economy.

According to Muliarto (2015), smart city is how to connect physical infrastructure, social infrastructure and economic infrastructure by using technology, which can integrate all elements in all aspect and thus could make the cities more efficient and livable. According to Giffinger (2007) in Mujiyono (2016), defines that the smart city is smart in doing the development of the city by looking forward. The approach of urban development that looks forward to the city intelligently considering issues, such as contribution, self-assertiveness, independence, and awareness. Giffinger (2007) in Mujiyono (2016) added that smart city has 6 (six) characteristics that must be possessed, such as: smart economy, smart mobility, smart environment, smart people, smart living, and smart governance. 


\section{RESEARCH METHOD}

\subsection{Research Focus}

This research was conducted in Paksebali village. This village is one of 12 villages in Dawan Subdistrict and it is located in the eastern of Semarapura City which is $1 \mathrm{Km}$ away. Paksebali village is also one of the villages that achieve Adi Pura award. Paksebali Village consists of 5 Banjar Dinas, namely Banjar Dinas Kanginan, Banjar Dinawan Kawan, Banjar Dinas Peninjoan, Banjar Dinas Bucu and Banjar Dinas Timbrah and it is divided into 8 Banjar/Pesamuan, namely Banjar Kanginan, Banjar Kawan, Banjar Peninjoan, Banjar Timbrah, Banjar Bucu, Puri Satria Kawan, Puri Satria Kaleran and Saturn Kanginan Castle. Paksebali village is included in Dawan District, Klungkung Regency, Bali Province. This village includes lowland areas with an altitude of $\pm 100 \mathrm{~m}$ above sea level, with boundaries as follows: North (Loka Sari Village, Sidemen Sub-district, Karangasem Regency), East (Sulang), South (Middle Sampalan Village), On the West (Unda River)

Paksebali village is an area that has an altitude of approximately 100 meters above sea level where a lot of natural potentials. The highlands of the village such as the hills, plantations and rivers. The natural potential that is in Paksebali Village has been managed by the community, especially in terms of plantations, the community is planting coconut, banana and tubers that have been the prior income of the community. In addition, there is the potential of nature that will be used as tourist attractions such as hills and rivers (Unda River), some of the certain potential is the livelihood of many diverse people either in the field of plantation, household industry, tourism, governmental sector as well as farm laborers.

\subsection{Type and Source of Data}

3.2.1 Types of data collected in this study were qualitative data, for instance data in the form of information and not in the form of numbers such as tourism potential, rural tourism management operational and public perception

3.2.2 The data source of this research was primary data that was data obtained directly from interview result and observation. Secondary data was data which was taken in the form of data that had been collected and analyzed, such it came from the documents associated with this research

\subsection{Research Respondents:}

The major respondents in this study were Paksebali local people who played an active role in the development of tourist villages Paksebali (Purposive sampling). Respondents were 30 people in total, with the following details:
1) Head of the village (perbekel)
$: 1$ people
2) Head of the neighborhood/kelian Banjar
: 5 people
3) Youth Chairman /Yuwa
$: 1$ people
4) Head of Sadar Wisata group /Bumdes
: 1 people
5) Village officers
: 2 people
6) Staff of Sadar Wisata group /Bumdes
: 2 people
7) BabinKamtibmas 

(Development of Security and Public Order)
: 1 people
8) The local communities
: 17 people

\subsection{Technique of Collecting Data}

In this research, the data collection techniques were:

a. Observation which was done by direct observation.

b. In-depth interviews which were done by conducting interviews with respondents about community perceptions and other data needed.

c. Documentation which was done by taking data through documents such as photos, files and others

\subsection{Technique of Analyzing Data}

The data obtained were analyzed by a qualitative descriptive technique which was presented by describing and elaborating systematically in the form of words which then concluded.

\section{THE FINDINGS AND DISCUSSION}

\subsection{Public Perception}

The public perceptions of the development of tourist village of Paksebali are described as follows:

a. In general the overall perception of the people is the already know that Paksebali village is being developed into a tourist village

b. The public perception towards the development of Paksebali village as a tourist village is very good and supporting the development of the tourist village. The support could be observed as follows:

1. Willing to maintain the cleanliness of the home environment and village, by not littering,

2. Willing to preserve nature and culture

3. Willing to maintain the security and comfort of the visitors

4. Willing to be polite and friendly to the visitors

5. Willing to receive visitors who want to see the house and its environment

c. The public perception of the benefits of developing a tourist village is that they hope Paksebali Village will be flocked by tourists both locally, domestically and internationally, therefore it could open employment opportunities for the community, reducing unemployment, promoting the on-going small enterprises especially the craftsmen, increasing the village income, and then reducing the burden of dues

4.2. Community participation in the development of Smart Eco-Village Destination With Tourist Village Based in Paksebali, Klungkung Regency, Bali Province

Public participation in the development of Paksebali tourist village in general is very good and active this is proven through the following observation: 


\subsubsection{Planning}

As a first step in the development of Paksebali tourist village, planning is done in terms of community participation planning in terms of:

a. Joining the tourism socialization about tourist village development plan from Klungkung regency government along with head of the village

b. Joining the tourism the meeting about the tourist village management plan which is mainly followed by prominent figures and banjar/neighborhood and village officials

c. Providing information and identifying tourism potential

d. Providing opinions or ideas about the development plans of tourist village

\subsubsection{The Implementation Development of Tourism Facilities and Infrastructure \\ The facilities and infrastructures in village development are an important part of its management of community participation as indicated by: \\ a. Engaging to work together in making and setting up the path for jogging tracks and cleaning the gutters \\ b. Engaging in training conducted by the manager of tourist village}

\subsubsection{Management}

Since the release of the decree from Klungkung Regency government about the determination of Paksebali Village as a tourist village, the management of the tourist village has started to be done even though it has not run in a maximum way. The community remains eager to participate in the management of both community members who are directly involved as well as supporting the development, the form of participation could be described as follows:

a. Citizens are participated as cooks, waitresses, parking attendants as well as security officers

b. For the community, especially those destinations which are developped as tourist attractions, the craftsmen are more organized in business to make the environment look cleaner, attractive and comfortable for visitors.

c. The community carries out sapta pesona such as maintaining the cleanliness of the house and its environment, maintaining the beauty of the environment, not littering the garbage, being friendly to the guests and maintaining the environment comfort and secured.

d. The community also promote about the Paksebali village by spreading word of mouth or through social media

\subsubsection{Monitoring and Evaluating}

The role of the community in monitoring and evaluating the tourist village management is importantly necessary, so that the management of the tourist village can run as expected. The form of community participations are:

a. Participating in supervision, especially to the behavior of the visitors, especially in a consecrated place.

b. Giving review and evaluation to the destination management if the irregularities in the management are found 


\section{CONCLUSION AND SUGGESTION}

\subsection{Conclusion}

Based on the research results and discussion, it can be concluded as follows:

a. The public perception towards the development of tourist village is generally very supportive and participative in the development of Paksebali tourist village

b. The community participation of Paksebali village in the development of tourist village is very active in planning, developing the facilities and infrastructure, as well as managing, monitoring and evaluating

\subsection{Suggestions}

Based on the conclusions of the research results, it could be suggested as follows:

a. In order to make better perception and participation of the community to develop eco-smart tourism destination, it should be continued by the stakeholders of the tourist village along with the hard work, honest and transparent.

b. In order to keep the community participation well maintained, the stakeholders and community leaders should always maintain good communication with the public through the socialization in some banjar in Paksebali village or always reporting the development of tourist village management at least once a year through annual report

c. In the management decision, tt should always prioritize the villagers as role-makers which can provide benefits to improve the welfare of people welfare

d. The stakeholders should conduct training, especially English language skills, improvement of the ability and skills as the cooks, waiters and tour guides 


\section{BIBLIOGRAPHY}

Adisasmita, Raharjo. 2006. Membangun Desa Partisipastif. Yogyakarta: Graha Ilmu.

Ariadi. 2017. Siap Jadi Desa Wisata Paksebali Buat Jalur "Tracking” di Perbukitan. BaliTravelNews.http://bali-travelnews.com/2017/01/26/siap-jadi-desawisata-paksebali-buat-jalur-tracking-di-perbukitan/. Diakses tanggal 7 Maret 2017.

Ariyanto. 2017. Pemerintah Dukung Pengembangan Desa Wisata Klugkung Bali. Infonawacita.com. https://www.infonawacita.com/pemerintah-dukungpengembangan -desa- wisata-klungkung-bali/. Diakses tanggal 7 Maret 2017.

Astrini, A.P. 2013. Analisis Upaya Masyarakat Dalam Mewujudkan Kampung Hijau, studi kasus Kelurahan Gayamsari, Kota Semarang. Tugas Akhir. Fakultas Teknik Jurusan Perencanaan Wilayah dan Kota, Univeristas Diponogoro.

Cooper, C. et all. 1993. Tourism Principles \& Practice. United Kingdom: Longman Group Limited.

Esram. M. J. 2006. Analisis Pasar Pariwisata dalam Pembangunan Kota Tanjung Pinang Provinsi Kepulauan Riau. Tesis. Semarang: Magister Pembangunan Wilayah dan Kota Undip.

Madiun, I N. 2008. "Partisipasi Masyarakat Lokal Dalam Pengembangan Kawasan Pariwisata Nusa Dua (Perspektif Kajian Budaya)". Disertasi. Program Studi Doktor Kajian Budaya, Program Pascasarjana Universitas Udayana. Denpasar.

Mujiyono, M dkk. 2016. Kesiapan Kota Pakalongan Menuju Smart City. Jurnal Litbang Kota Pekalongan. 11(1): 107-116.

Nashuilia, AP. 2015. Desa Pintar. http://azzradesapintar.blogspot.co.id/. Diakses tanggal 8 Maret 2017.

Priasukmana, S \& R.M. Mulyadi. 2001. Pembangunan Desa Wisata: Pelaksanaan Undang-Undang Otonomi Daerah. Info Sosial Ekonomi. 2 (1): 37-44.

Rahayu, W.P. dkk. 2003. Klasifikasi Bahan Pangan dan Resiko Keamanannya. Jakarta: PT. Gramedia Pustaka Utama.

Rakhmat, J. 2007. Persepsi Dalam Proses Belajar Mengajar. Jakarta: Rajawali Pers.

Rangkuti, F. 2006. Measuring Customer Satisfaction. Jakarta: PT. Gramedia Pustaka Utama.

Rencana Strategis Dinas Pariwisata Kabupaten Klungkung 2013-2018. 
Shodiq, J. 2009. Perencanaan Kampung Berbasis Lingkungan (Ecovillage) di Kawasan Penyangga Taman Nasional Ujung Kulon Banten. Skripsi. Program Studi Arsitektur Lanskap, Fakultas Pertanian, Institut Pertanian Bogor.

Sudria munawar, Haryono. 2006. Kepemimpinan, Peran Serta, Produktivitas. Bandung: Mandar Maju.

Sunaryo, B. 2013. Kebijakan Pembangunan Destinasi Pariwisata Konsep dan Aplikasinya Indonesia. Yogyakarta: Gava Media.

Tunjungsari, K.R. 2016. Persepsi Masyarakat Kuta Terhadap Dampak Pembangunan Hotel Berkonsep City Hotel di Sunset Road Kuta Bali. Proposal Penelitian. Dikti.

Undang-undang Republik Indonesia No 10 tahun 2009 tentang Kepariwisataan

Undang-undang Republik Indonesia No 10 tahun 2009 tentang Kepariwisataan

Yoeti, O.A. 2002. Perencanaan dan Pengembangan Pariwisata. Jakarta: PT Pradaya Paramita.

Yustina, K. 2015. Promosi Pariwisata di Media Online Dianggap 4 Kali Lebih Efektif. TravelNews. Com. 